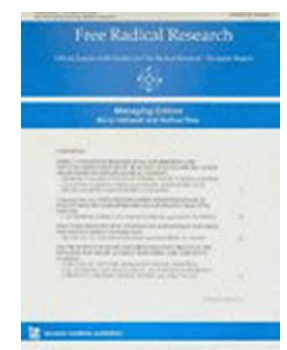

\title{
The Contributions of Oxidative Stress, Oxidised Lipoproteins and AMPK Towards Exercise-Associated PPARy Signalling within Human Monocytic Cells
}

\begin{tabular}{|r|l|}
\hline Journal: & Free Radical Research \\
\hline Manuscript ID: & Draft \\
\hline Manuscript Type: & Original Manuscript \\
\hline Date Submitted by the Author: & $\mathrm{n} / \mathrm{a}$ \\
\hline Complete List of Authors: & $\begin{array}{l}\text { Davies, Nia; Cardiff Metropolitan University, Biomedical Sciences } \\
\text { Watkeys, Laura; Cardiff Metropolitan University, Biomedical Sciences } \\
\text { Butcher, Lee; Cardiff Metropolitan University, Biomedical Sciences } \\
\text { Potter, Steve; Cardiff Metropolitan University, Biomedical Sciences } \\
\text { Hughes, Michael; Cardiff Metropolitan University, Cardiff School of Sport } \\
\text { Moir, Hannah; Kingston University, School of Life Sciences } \\
\text { Morris, Keith; Cardiff Metropolitan University, Biomedical Sciences } \\
\text { Thomas, Andrew; Cardiff Metropolitan University, Biomedical Sciences } \\
\text { Webb, Richard; Cardiff Metropolitan University, Biomedical Sciences }\end{array}$ \\
\hline Keywords: & $\begin{array}{l}\text { Exercise, oxidative stress, Reactive Oxygen Species (ROS), vitamin E, } \\
\text { vitamin C, redox sensitive transcription factor (PPARgamma) }\end{array}$ \\
\hline
\end{tabular}

\section{SCHOLARONE ${ }^{m}$}

Manuscripts 


\section{The Contributions of Oxidative Stress, Oxidised Lipoproteins and AMPK Towards Exercise-Associated PPAR $\gamma$ Signalling within Human Monocytic Cells}

Davies, N.A., Watkeys, L., Butcher, L., Potter, S., Hughes, M.G. ${ }^{1}$, Moir, H. ${ }^{2}$, Morris, K., Thomas, A.W. and Webb, R.

Cardiff School of Health Sciences, Cardiff Metropolitan University, Cardiff CF5 2YB, UK; ${ }^{1}$ Cardiff School of Sport, Cardiff Metropolitan University, Cardiff CF23 6XD, UK; ${ }^{2}$ School of Life Sciences, Kingston University, London KT1 2EE.

(corresponding author: R. Webb, Cardiff School of Health Sciences, Cardiff Metropolitan University, Cardiff CF5 2YB, UK; email: rwebb@cardiffmet.ac.uk; tel: 00-44-2920416871; fax: 00-44-2920-416982)

Key Words: PPAR $\gamma$, exercise-associated oxidative stress, monocytes, antioxidant supplementation, AMPK. 
ABSTRACT. PPAR $\gamma$ is known to be activated via exercise-associated transient increases in oxidative stress. However, the precise mechanism(s) triggering PPAR $\gamma$ activation in monocytes during/following exercise remain to be confirmed. Here, two cohorts of five healthy male individuals undertook exercise bouts (cycling; $70 \% \dot{\mathrm{VO}}_{2} \max ; 45 \mathrm{~min}$ ) in the presence/absence of dietary antioxidant supplementation (vitamins C (1000mg/day) and E (400IU/day) for four weeks prior to exercise), and monocytic AMPK/PGC-1 $\alpha /$ PPAR $\gamma$ signalling was investigated in samples obtained pre- and up to $24 \mathrm{~h}$ post-exercise, while THP-1 cells were cultured as an in-vitro monocyte model. In THP-1 cells, AMPK $\alpha 1$ was phosphorylated within $1 \mathrm{~h}$ of menadione $(15 \mu \mathrm{M})$-triggered increases in $[\mathrm{ROS}]_{\mathrm{cyto}}$, an effect which was followed by upregulation of PPAR $\gamma$ and several of its target genes (PGC-1 $\alpha$, LXR $\alpha$, ABCA1; 24-72h), with these effects being blunted by co-administration of Vitamin $\mathrm{C}(62.5 \mu \mathrm{M})$. Conversely, treatment with oxLDL $(1 \mu \mathrm{g} / \mathrm{mL} ; 24-72 \mathrm{~h})$, but not non-oxidised LDL, upregulated the above PPAR $\gamma$-regulated genes without affecting AMPK $\alpha 1$ phosphorylation. In-vivo, dietary antioxidant supplementation (which is known to prevent exercise-triggered increases in oxLDL levels) blunted exercise-associated upregulation of the above PPAR $\gamma$-regulated genes, but had no effect on exercise-associated transient $[\mathrm{ROS}]_{\text {cyto }}$ increases, or on AMPK phosphorylation. These data suggest that exerciseassociated PPAR $\gamma$ signalling effects appear, at least in monocytes, to be mediated by increased generation of PPAR $\gamma$ ligands via oxidation of lipoproteins (following exerciseassociated transient increases in oxidative stress), rather than via $[\mathrm{ROS}]_{\text {cyto }}$-mediated AMPK activation. These findings may be of clinical relevance, as PPAR $\gamma$ activation in monocytes is associated with beneficial effects related to Type-2 Diabetes and its cardiovascular complications. 


\section{Introduction.}

Exercise is well recognised as a systemic oxidative stressor [1-5]. This has been attributed to reactive oxygen species (ROS) being released from contracting skeletal myocytes; for example, $\mathrm{H}_{2} \mathrm{O}_{2}$ 's long half-life is known to permit its diffusion across the myocyte membrane and thence its transport to other regions of the body $[1,2]$. Direct measurement of extracellular concentrations of ROS has detected increases from $\sim 10 \mu \mathrm{M}$ to $\sim 25 \mu \mathrm{M}$ during exercise [5], while Jackson has stated that: "muscle is able to release ROS...these ROS are capable of leading to an increased systemic oxidation, including in non-contracting tissues" [1]. Because the magnitude of this exercise-associated increase in ROS is quite modest ( $\sim$ two-fold increases, culminating in peak intracellular ROS concentrations of $\sim 100 \mathrm{nM}[6]$ ), the effects of this increase are more likely to involve redox-sensitive signalling effects than oxidative damage [1]. Accordingly, changes in gene expression can be induced by ROS produced during muscular contractions [7], and the resulting effects can be of clinical significance.

The ligand-activated nuclear receptor 'Peroxisome Proliferator Activated Receptorgamma' (PPAR $\gamma)$ and its associated transcriptional coactivator 'PPAR $\gamma$ Coactivator1alpha' (PGC-1 $\alpha$ ) comprise a signalling system that appears to be subject to activation via this route. Exercise leads to increased PPAR $\gamma$ activity $[3,8]$, and increased PPAR $\gamma$ and PGC-1 $\alpha$ expression $[9,10]$, within skeletal muscle, while transcriptional mapping of the effects of exercise on skeletal muscle has shown that many PGC-1 $\alpha /$ PPAR $\gamma-$ regulated genes were among the genes upregulated [11]. PPAR $\gamma$ and PGC-1 $\alpha$ are regulators of the expression of numerous target genes (ie. genes bearing PPAR $\gamma$ Response Elements (PPREs), to which activated PPAR $\gamma$ can bind) involved in antioxidant defence, metabolism, cell differentiation and inflammation $[12,13]$. Therefore, synthetic agonists for PPAR $\gamma$ (eg. thiazolidinediones 
such as rosiglitazone [14]) have been widely used to elicit beneficial effects in the contexts of Type-2 Diabetes (T2D) and cardiovascular risk [15]. However, the linking of rosiglitazone to negative patient outcomes (ie. increased risk of myocardial infarction/death from cardiovascular causes [16-18]) has raised safety concerns and in the light of these concerns, prescription of rosiglitazone has fallen dramatically in recent years [19]. Therefore, alternative means of inducing beneficial PPAR $\gamma$ dependent effects without also causing such deleterious effects are urgently required.

In line with the observation that the PPAR $\gamma / \mathrm{PGC}-1 \alpha$ system responds to oxidative stress [20], Ristow et al reported that dietary supplementation with antioxidants prevented some of the systemic cardiovascular risk-lowering effects of physical exercise, with increased signalling via PPAR $\gamma / \mathrm{PGC}-1 \alpha$ being seen after exercise only in the absence of antioxidants [21]. Similar findings were obtained using a range of different antioxidants in several other studies [22-26]; these findings were proposed to extend the concept of 'hormesis' (defined as: “repeated exposure to sublethal stress that cumulates in enhanced stress resistance and ultimately increased survival rates" [27]) to the field of exercise-triggered cell signalling [4]. Hence, whereas prolonged exposure to high levels of ROS brings about cell damage, repeated exerciseassociated transient increases in ROS may - via triggering of PPAR $\gamma /$ PGC- $1 \alpha$ signalling - underpin adaptive signalling processes which ultimately prove to be beneficial to health $[4,21]$.

However, the cellular aspects of the above studies were confined to skeletal myocytes, and to the beneficial consequences of exercise-induced signalling via PPAR $\gamma / \mathrm{PGC}-1 \alpha$ within myocytes (e.g. mitochondrial biogenesis, antioxidant defence). Importantly, given the systemic nature of the impact of exercise, and the contribution of nonmuscle cells to the systentije:/responsentusexiptcise,tutheceris/gfineed to establish whether 
exercise-associated cell signalling within non-muscle cell types is also prevented by dietary antioxidant supplementation. The current study focuses on the effects of exercise-associated oxidative stress on monocytes, as it is well-established that monocytes are an exercise-responsive cell-type (eg. they infiltrate into tissues in the 24-48h following each exercise bout in order to regulate local inflammation and mediate tissue repair/remodelling [28]). Also, it should be noted that PPAR $\gamma$ is known to regulate inflammatory responses and atherogenesis via its actions within this cell type $[20,29]$, and that activation of PPAR $\gamma$ within monocyte-macrophages has been shown to be crucial to the systemic insulin-sensitising/anti-hyperglycaemic actions of rosiglitazone [30]. Finally, because monocytes are relatively easily collected, exercise-associated signalling effects within monocytes may potentially be feasible for use as novel 'biomarkers' for systemic PPAR $\gamma$-mediated exercise-linked benefits [31].

We have previously demonstrated that participation in exercise can affect PPAR $\gamma /$ PGC-1 $\alpha$-mediated signalling events within monocytes [32-35]. Participation in an 8-week low-intensity exercise programme induced upregulation of several PPAR $\gamma$ target genes in monocytes, and this was associated with altered serum lipid profiles (increased HDL-C; decreased total cholesterol, LDL-C and triglycerides), indicating that exercise had enhanced reverse cholesterol transport via its effects on PPAR $\gamma$ signalling within monocytes [32]. Similarly, participation in low-intensity exercise exerted systemic anti-inflammatory effects that were linked to priming of monocytes for differentiation into the alternative M2 macrophage phenotype [35].

Importantly, however, these studies did not identify a precise mechanism for linking exercise with PPAR $\gamma$ activation in monocytes. Conflicting explanations have been put

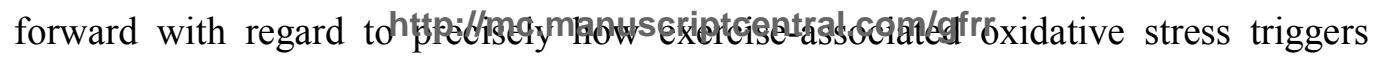


PPAR $\gamma$ signalling. Specifically, because exercise-associated oxidative stress oxidises circulating lipoproteins, and the resulting oxidised lipoprotein (oxLDL) particles contain distinct chemical species to those contained within non-oxidised LDL (e.g. modified fatty acids, which would be plausible candidates for roles as PPAR $\gamma$ ligands [19]), exercise may trigger PPAR $\gamma$-mediated transcriptional responses via generation of oxLDL $[32,36]$. In support of this, our previous observation that serum from exercising participants elicits PPRE-luciferase reporter gene activation in an in vitro system [34] suggests that exercise may be associated with generation of blood-borne PPAR $\gamma$ ligands. Alternatively, monocytes can either take up exogenous reactive oxygen species (ROS), such as that generated by contracting muscle [1-2]), or can generate ROS endogenously via the actions of monocyte-expressed agents such as NADPH oxidase [33]. Because the exercise-activated intracellular kinase AMPK (which has been known to play an active signalling role within monocytes for over a decade [37]) can be activated by increased levels of cytoplasmic ROS ([ROS $]_{\text {cyto }}$ ) [38], and because PGC-1 $\alpha$ is a substrate for AMPK [39], it has been suggested that a $\mathrm{ROS} \rightarrow \mathrm{AMPK} \rightarrow \mathrm{PGC}-1 \alpha$ cascade may underpin exercise's impact upon PPAR $\gamma$ regulated patterns of gene expression [40].

Therefore, in the present study we aimed to test the hypotheses that exercise/oxidative stress-associated PPAR $\gamma$-mediated signalling responses within monocytes may be triggered via either generation of exercise-associated blood-borne PPAR $\gamma$ ligands, and/or activation of an intracellular $\mathrm{ROS} \rightarrow \mathrm{AMPK} \rightarrow \mathrm{PGC}-1 \alpha \rightarrow \mathrm{PPAR} \gamma$ signalling axis; and that such responses may be prevented (or at least blunted) by dietary antioxidant supplementation.

\section{Methods.}

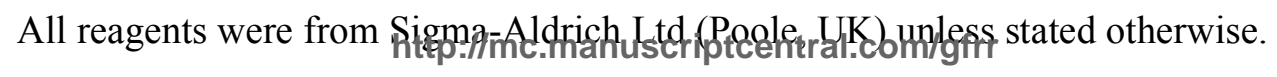


Participant recruitment and exercise procedures. Two cohorts of healthy active male individuals (Group A (Exercise-alone): $\mathrm{n}=5$; age: $32 \pm 8$ years; height: $179 \pm 11 \mathrm{~cm}$; body mass: $80 \pm 11 \mathrm{~kg}$; Group B (Exercise+Antioxidants): n=5; age: 32 \pm 6 years; height: $175 \pm 7 \mathrm{~cm}$; body mass: $79 \pm 10 \mathrm{~kg}$ ) were recruited to participate in the exercise study. All participants completed informed consent forms, and ethical approval was granted by the Cardiff Metropolitan University School of Health Sciences Research Ethics Committee; thus the study conforms to the principles outlined in the Declaration of Helsinki. In accordance with Ristow et al. [21], participants in Group B undertook dietary supplementation in the form of vitamins C (1000 mg/day) and E (400 IU/day) for 4 weeks prior to the exercise intervention. Both cohorts fasted overnight before undertaking exercise; standardization of food intake and physical activity prior to exercise was achieved via use of health/activity questionnaires. Exercise procedures were performed on a Monark 824E cycle ergometer (Monark Exercise AB, Varberg, Sweden). Participants first performed an incremental cycling test to exhaustion; each stage of the test lasted $3 \mathrm{~min}$, and the required power output increased by $30 \mathrm{~W}$ at every stage until volitional exhaustion. Once maximal oxygen consumption $\left(\dot{\mathrm{V}}_{2} \max \right)$ had been established (Group A: $44 \pm 14 \mathrm{ml} / \mathrm{kg} / \mathrm{min}$; Group B: $48 \pm 9 \mathrm{ml} / \mathrm{kg} / \mathrm{min}$ ), the power output corresponding to $70 \% \dot{\mathrm{VO}}_{2}$ max was calculated for each participant; this intensity was used in a subsequent single $45 \mathrm{~min}$ bout of exercise. In all cases, heart rate was monitored throughout using a Polar S810 HR monitor (Polar Electro, Oy, Finland), $\dot{\mathrm{V}}_{2}$ was monitored using a Jaeger Oxycon Delta system (Erich Jaeger GMBH \& Co., Hoechberg, Germany), and capillary blood samples were taken every 15min using finger capillary samples for determination of blood lactate concentration using an Analox GM7 Microstat analyser (Analox Instruments, London, UK).

Isolation of human peripheral mononuclear cells from whole blood. Blood samples

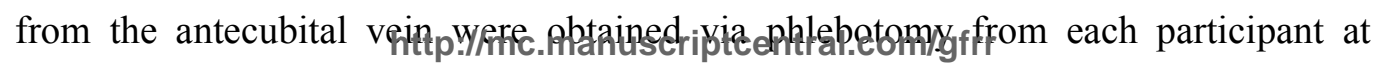


baseline ('pre'), immediately following exercise ('post') and $1.5 \mathrm{~h}, 3 \mathrm{~h}$ and $24 \mathrm{~h}$ after exercise. For isolation of peripheral blood mononuclear cells, $10 \mathrm{ml}$ of heparinised blood was diluted 1:1 in Roswell Park Memorial Institute cell culture medium 1640 (RPMI), layered over 10ml of Histopaque-1077 Ficoll-Hypaque and centrifuged at $400 \mathrm{X}$ G for $20 \mathrm{~min}$. Mononuclear cell suspensions were carefully removed from the Ficoll-Hypaque interface, and washed four times (500 X G; 10min) in $0.4 \mathrm{ml}$ of Active Motif phosphate inhibitor solution and $7.6 \mathrm{ml}$ Phosphate-Buffered Saline (PBS), before being subjected to flow cytometry, or harvesting of protein or RNA extracts (see below). It should be noted that leukocyte vitamin $\mathrm{C}$ content does not alter during this extraction procedure [24].

Maintenance of cells in culture. Cells from the monocytic THP-1 cell line ([39]; obtained from ATCC (Teddington, UK)) were allowed to grow and propagate under controlled conditions $\left(37^{\circ} \mathrm{C}\right.$; in a humidified $5 \% \mathrm{CO}_{2}$ atmosphere) in RPMI supplemented with $1 \% \mathrm{v} / \mathrm{v}$ penicillin/streptomycin, $10 \% \mathrm{v} / \mathrm{v}$ fetal calf serum, $1 \%$ v/v non-essential amino acids, $1 \%$ L-glutamine and 1\% v/v sodium pyruvate. Cells were seeded at $\sim 0.3 \times 10^{6}$ cells $/ \mathrm{ml}$ and passaged at $\sim 1 \times 10^{6}$ cells $/ \mathrm{ml}$ after a growth period of 3-4 days. Experiments were routinely performed with cells at passage $<25$, and at viability $>95 \%$ as measured by trypan blue exclusion. Samples $\left(5 \times 10^{6}\right.$ cells $)$ were incubated with the macrolide antibiotic oligomycin (a mitochondrial ATP synthase inhibitor; $1 \mu \mathrm{M})$, the $\mathrm{H}_{2} \mathrm{O}_{2}$ donor menadione $(15 \mu \mathrm{M})$, the antioxidant vitamin $\mathrm{C}(62.5 \mu \mathrm{M})$, commercially available preparations of oxidized low-density lipoprotein (oxLDL) and non-oxidised low-density lipoprotein (LDL) (Autogen Bioclear Ltd [Nottingham, UK]; $1 \mu \mathrm{g} / \mathrm{mL}$ in both cases - this corresponds approximately to serum oxLDL levels seen in sedentary individuals in our previous studies [32]); and 13-hydroxyoctadecadienoic acid (13-HODE; $5 \mu \mathrm{M})$ at $37^{\circ} \mathrm{C}$ for the indicated times. 
Flow cytometric measurements of $[R O S]_{\text {cyto }}$. $[\mathrm{ROS}]_{\mathrm{cyto}}$ quantitation was achieved by following (with minor modifications) the method of Hirpara et al [42], which utilised dichlorodihydrofluorescin diacetate $\left(\mathrm{H}_{2} \mathrm{DCFDA}\right)$ as an indicator sensitive to a number of ROS including $\mathrm{H}_{2} \mathrm{O}_{2}$, superoxide, nitric oxide and peroxynitrite [1]. THP-1 cells treated for $1 \mathrm{~h}$ with menadione $(15 \mu \mathrm{M}) \pm$ vitamin $\mathrm{C}(62.5 \mu \mathrm{M})$, or mononuclear cell samples from the cycling cohort, were subjected to flow cytometric analysis. In the latter case, leukocytes (extracted from whole blood via incubation for 10 min with Optilyse C Lysis Solution (Beckman Coulter, Buckinghamshire, UK) to lyse erythrocytes) were centrifuged (5min; $300 \mathrm{X} \mathrm{G}$ ), washed and resuspended in PBS at a concentration of $10^{5} \mathrm{cells} / \mathrm{ml}$. $100 \mu \mathrm{L}$ cell aliquots of THP-1 cells, or leukocytes taken pre- and up to $24 \mathrm{~h}$ post-exercise, were loaded with $\mathrm{H}_{2}$ DCFDA (Molecular Probes, Eugene, OR, USA; $\left.2.5 \mu \mathrm{M} ; 10 \mathrm{~min} ; 4^{\circ} \mathrm{C}\right)$, washed, and the resulting fluorescence $\left(\lambda_{\mathrm{ex}}\right.$ $=495 \mathrm{~nm} ; \lambda_{\mathrm{em}}=524 \mathrm{~nm}$ ) analysed using a Beckman FACS FC500 flow cytometer (Becton Dickinson, Mountain View, CA, USA). [ROS $]_{\text {cyto }}$ values were compared for samples taken 'pre' and 'post' exercise, and for treated versus control THP-1 samples. Separate electronic 'gates' were set with regard to forward and side scatter to differentiate between different subpopulations of leukocytes, and thus to specifically quantitate $[R O S]_{\mathrm{cyto}}$, within monocytes.

Western blot analysis. Western blot experiments were carried out as described previously [33]. Briefly, total protein extracts from THP-1 cells, or mononuclear cell samples from the cycling cohort, were prepared by treatment with $100 \mu$ of Protein Extraction/Lysis buffer, containing $1 \mathrm{mM}$ Protease inhibitor cocktail and $1 \mathrm{mg} / \mathrm{ml}$ phosphatase inhibitor (Active Motif Ltd, Rixensart, Belgium). Protein content was then estimated using a Bio-Rad protein assay (Bio-Rad Laboratories, Basingstoke,

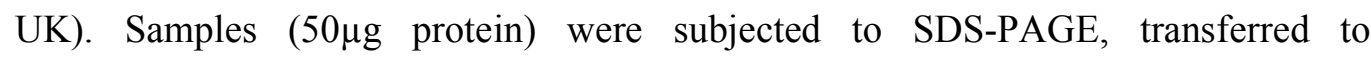
nitrocellulose membranestpand probed wwith primary antibadies (16h), followed by 
HRP-labelled anti-rabbit IgG antibody (2h; 1:2000 dilution; Cell Signalling Tech., Danvers, MA, USA). Immunogenic bands were detected via enhanced chemiluminescence (West Pico Dura Luminol/enhancer substrate, Rockford, IL, USA). using a UVP Bioimaging AutoChemi system (UVP, Cambridge UK). The following primary antibodies were used: anti-phospho-AMPK (threonine residue 172) (1:1000; Cell Signalling Tech., Danvers, MA, USA); anti-AMPK $\alpha 1$ (1:1000; Cell Signalling Tech., Danvers, MA, USA); anti-PGC-1 $\alpha$ (1:1000; Cell Signalling Tech., Danvers, MA, USA). Anti- $\beta$-actin antibodies (1:1000; Cell Signalling Tech., Danvers, MA, USA) were used for normalisation purposes, in order to confirm equal loading of samples. Activation of AMPK was expressed as the ratio of phosphorylated to total AMPK $\alpha 1$, as detected as $63 \mathrm{KDa}$ immunogenic bands on Western blots using antibodies directed against and total AMPK $\alpha 1$ respectively. PGC-1 $\alpha$ was detected as $\sim 115 \mathrm{KDa}$ and $\sim 105 \mathrm{KDa}$ immunogenic bands on western blots. Specificity of immunoreactivity in anti-PGC-1 $\alpha$ Western blots was confirmed using addition of a PGC-1 $\alpha$ blocking peptide to the primary antibody incubation step (5-fold excess by weight of peptide:IgG; Autogen Bioclear Ltd, Wiltshire, UK).

Isolation of RNA and RT-PCR assays. The extraction of total RNA was carried out using a RiboPure-Blood Kit (Ambion ${ }^{\circledR}$, Huntingdon, UK) according to manufacturers' instructions. Briefly, $5 \times 10^{6}$ THP-1 or mononuclear cells were washed in ice-cold PBS, lysed and RNA extracted using acid phenol-chloroform extraction, ethanol precipitation, and resuspension in RNAase-free water. RNA was quantified and checked for purity using the ratio of its absorbance at 260:280nm (only samples of ratio $>1.8$ being deemed suitable for use). RNA samples were stored at $-80^{\circ} \mathrm{C}$ before conversion to cDNA using an Applied Biosystems ${ }^{\circledR}$ High-Capacity cDNA Archive Kit (Applied Biosystems, Warrington, UK) and storage at $-20^{\circ} \mathrm{C}$. LXR $\alpha, \mathrm{ABCA} 1$, 
PPAR $\gamma$ and PGC-1 $\alpha$ mRNA expression were analysed using Fast SYBR Green Master Mix (Applied Biosystems, Warrington, UK), and compared with that of Glyceraldehyde Phosphate Dehydrogenase (GAPDH). Importantly, preliminary experiments showed that mRNA expression for these genes was significantly enriched (2.5- to 6-fold) in purified monocytes (obtained using commercial QuadroMACS separator units, LS columns and CD14 MicroBeads (Miltenyi Biotec, Bisley, UK) according to the manufacturers' instructions) compared with in mixed mononuclear cell samples [data not shown], indicating that the cDNA species detected in our RTPCR experiments are derived from monocyte subsets within the original mononuclear cell samples. Primers with the following sequences were designed using Primer

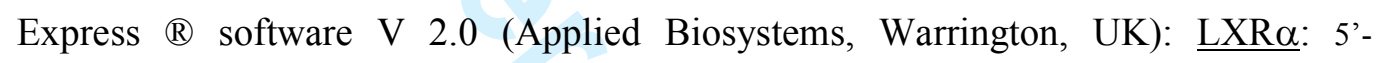

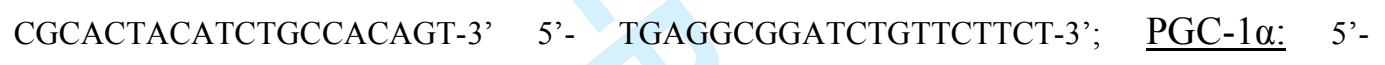

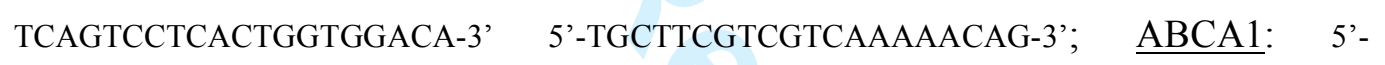

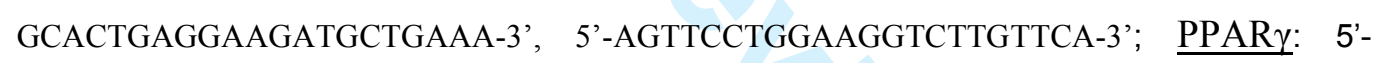

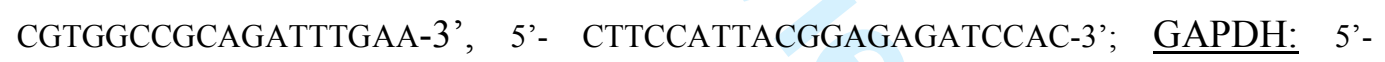
TCCTGTGGCATCCACGAA-3' 5'-GAAGCATtTGCGGTGGAC-3'. Thermocycling was as follows: initial denaturation for $10 \mathrm{~min}$ at $95^{\circ} \mathrm{C}$, followed by 40 cycles of $15 \mathrm{sec}$ at $95^{\circ} \mathrm{C} / 60 \mathrm{sec}$ at $60^{\circ} \mathrm{C}$. Relative quantification of target genes was calculated using the $2^{-}$

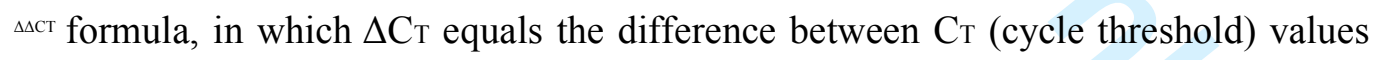
for gene-of-interest and housekeeping gene.

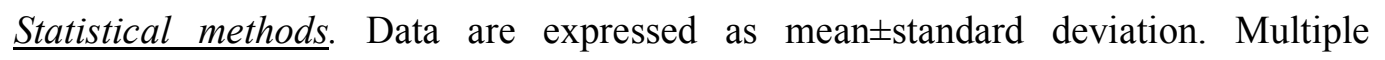
between-group and within-group comparisons were performed using two-way or oneway analysis of variance (ANOVA) respectively, with post-hoc analysis performed using Tukey's method in each case. For non-multiple comparisons, 2-sample t-tests were used. Significance levels were set at $P<0.05 \quad(P<0.10$ was referred to as

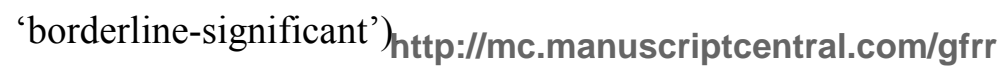




\section{Results.}

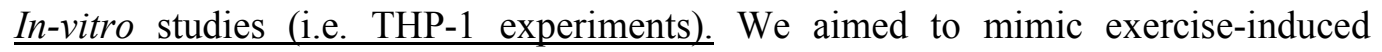
increases in $[R O S]_{\text {cyto }}$ by treating THP-1 cells with the $\mathrm{H}_{2} \mathrm{O}_{2}$ donor menadione, and also used the mitochondrial ATP synthase inhibitor oligomycin as a positive control for AMPK activation. The properties of both reagents were confirmed in our experiments: menadione treatment $(15 \mu \mathrm{M} ; 1 \mathrm{~h})$ led to significant increases in $[R O S]_{\text {cyto }}$ within THP-1 cells $(355.8 \pm 43.4 \%$ basal; $\mathrm{P}<0.05$ [1-way ANOVA]; Fig $1 \mathrm{~A})$, while $1 \mu \mathrm{M}$ oligomycin induced a significant decrease in THP-1 intracellular ATP content within $10 \mathrm{~min}(62.9 \pm 6.0 \%$ basal; $\mathrm{P}<0.05$ [1-way ANOVA]; data not shown). Moreover, menadione-induced increases in $[\mathrm{ROS}]_{\mathrm{cyto}}$ were significantly blunted by co-administration with Vitamin C $(62.5 \mu \mathrm{M}$; P<0.05 [2-way ANOVA]; Fig 1A).

As AMPK can be activated by both cellular energy depletion [43] and increased $[\mathrm{ROS}]_{\text {cyto }}[38]$, we next investigated the effects of oligomycin and menadione on activation of AMPK $\alpha 1$, as represented densitometrically by the ratio of phosphorylated to total AMPKal within total protein extracts from THP-1 cells. Oligomycin treatment led to approximately two-fold AMPK $\alpha 1$ activation (5 min; $208.7 \pm 46.4 \%$ basal; $\mathrm{P}<0.05$ [2-sample t-test]; Figs $1 \mathrm{~B}$ and $1 \mathrm{C}$ ), while menadione was associated with approximately three-fold AMPK activation (1h; $346.8 \pm 16.3 \%$ basal; $\mathrm{P}<0.05$ [2-sample t-test]; Figs $1 \mathrm{~B}$ and 1C). Once again, menadione-induced effects were significantly blunted by co-administration with Vitamin $\mathrm{C}(\mathrm{P}<0.05$ [2-way ANOVA]; Figs 1B and 1C). We also treated THP-1 cells with oxLDL (1-72h; $1 \mu \mathrm{g} / \mathrm{mL}$ ), but this reagent did not significantly increase AMPK phosphorylation $(\mathrm{P}>0.05$ [2-sample t-test]; Figs 1B and 1C).

Jäger et al have reported that PGC-1 $\alpha$ is a substrate of AMPK in skeletal muscle [39];

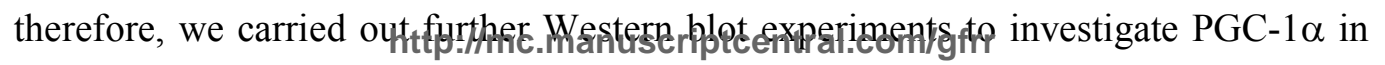


THP-1 cells. As shown in Fig 2, a doublet of immunogenic bands of molecular weights $\sim 105$ and $\sim 115 \mathrm{KDa}$ was detected on anti-PGC-1 $\alpha$ western blots, with both bands being competed out by addition of a PGC-1 $\alpha$ blocking peptide to the primary antibody incubation step (5-fold excess by weight of peptide:IgG (i.e. $\sim 1 \mu \mathrm{g} / \mathrm{ml}$ )). After $1 \mathrm{~h}$ treatment with oligomycin or menadione, the larger molecular weight form pre-dominated $(115 \mathrm{KDa}$ band:doublet ratios: $0.38 \pm 0.03$ (control); $0.85 \pm 0.05$ (oligomycin; $\mathrm{P}<0.05$ [2-sample t-test]); $0.63 \pm 0.06$ (menadione; $\mathrm{P}<0.05$ [2-sample ttest]). Co-administration with vitamin $\mathrm{C}$ appeared to blunt menadione's effect, albeit without attaining statistical significance $(115 \mathrm{KDa}$ band:doublet ratio: $0.53 \pm 0.04$; $\mathrm{P}>0.05$ [2-way ANOVA]), while neither oxLDL $(0.32 \pm 0.06 ; \mathrm{P}>0.05$ [2-sample ttest]) nor LDL $(0.36 \pm 0.11 ; \mathrm{P}>0.05$ [2-sample t-test] $)$ affected the respective levels of the two bands within the doublet. Because post-translational modifications such as phosphorylation reduce substrate proteins' electrophoretic mobility, this may indicate that activated AMPK $\alpha 1$ phosphorylates PGC-1 $\alpha$ in oligomycin- or menadione-treated THP-1 cells.

Given that phosphorylation of PGC- $1 \alpha$ leads to its activation as a transcriptional coactivator [39], we next investigated the effects of the above treatments on the expression of PPAR $\gamma /$ PGC-1 $\alpha$ target genes. These include LXR $\alpha$ (whose upregulation leads to consequent upregulation of the $\operatorname{LXR} \alpha$ target gene $\mathrm{ABCA} 1$ ), and also the PPAR $\gamma$ and PGC-1 $\alpha$ genes themselves (whose promoters contain PPAR $\gamma$ response elements) $[32,35,44,45]$. In these genes, mRNA expression was increased by $1.5-4-$ fold following 24h treatment with oligomycin (Fig 3; P<0.05 [1-way ANOVA] where indicated), but returned approximately to basal levels within $72 \mathrm{~h}$ (in contrast, mRNA expression of the AMPK $\alpha 1$ gene was unchanged throughout $72 \mathrm{~h}$ of oligomycin treatment (data not shown)). Treatment with menadione induced highly significant 
increases in gene expression of PGC- $1 \alpha$ and PPAR $\gamma$ (Fig 3; P $<0.01$ [1-way ANOVA]), and borderline-significant increases in gene expression of LXR $\alpha$ and ABCA1 ( $<0.10$ [1-way ANOVA]), while direct comparison of menadione versus menadione-plus-vitamin-C showed significant blunting of menadione's effects by coadministration with vitamin $\mathrm{C}$ in 3 out of the 4 genes (ABCA1, PPAR $\gamma-\mathrm{P}<0.01$; LXR $\alpha-\mathrm{P}<0.05$ [2-way ANOVA]).

Interestingly, although oxLDL did not induce phosphorylation of either AMPKa1 or PGC-1 $\alpha$ (see Figs 1 and 2), mRNA expression of PGC-1 $\alpha$ and LXR $\alpha$ appeared to increase in oxLDL-treated samples (Figs 4A and 4B), either significantly as compared to non-oxidised LDL $(\mathrm{P}<0.05$ [2-way ANOVA]: LXR $\alpha)$, or non-significantly $(\mathrm{P}>0.05$ [2-way ANOVA]: PGC-1 $\alpha$ ). As 13-HODE has previously been identified as both a breakdown product of oxLDL and a PPAR $\gamma$ ligand [34,36], THP-1 cells were treated with 13-HODE $(5 \mu \mathrm{M} ; 24 \mathrm{~h})$ in an additional experiment. As shown in Fig $4 \mathrm{C}$, expression of PGC-1 $\alpha$ and LXR $\alpha$ underwent significant 2-4-fold increases (PGC-1 $\alpha$ $\mathrm{P}<0.01 ; \mathrm{LXR} \alpha-\mathrm{P}<0.05$ [1-way ANOVA]) following 13-HODE treatment. Finally, given the lack of statistical significance seen for PGC- $1 \alpha$ mRNA expression in the RT-PCR experiment shown in Fig 4A, total PGC-1 $\alpha$ protein expression (ie. expression of both bands within the above doublet on Western blots; $\beta$-actin was used for normalisation purposes, in order to confirm equal loading of samples) was assessed: as shown in Figs 4D and 4E, PGC-1 $\alpha$ underwent significant increases following $48 \mathrm{~h}$ treatment with menadione $(\mathrm{P}<0.05$ as compared to menadione-plusvitamin-C [2-way ANOVA]), or with oxLDL ( $<<0.05$ as compared to non-oxidised LDL [2-way ANOVA]).

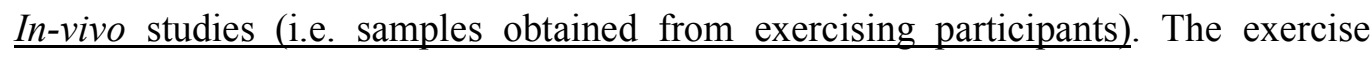
intervention used was similar to that utilised in our previous studies [33], with the 
exception that two comparable cohorts were recruited, one of which undertook dietary antioxidant supplementation for 4 weeks before undertaking exercise (Group B), while the other did not (Group A). The physiological stresses resulting from the bouts of exercise, as indicated by mean heart rate, blood lactate concentration and $\dot{\mathrm{V}}_{2}$, were not significantly different between the two cohorts (data not shown), indicating that exercise was performed at a comparable intensity in all cases.

Analysis via $\mathrm{H}_{2}$ DCFDA fluorescence-mediated flow cytometry of monocytes obtained from exercising participants indicated that transient, $\sim 2$-fold increases in $[R O S]_{\text {cyto }}$ were seen in monocytes within $3 \mathrm{~h}$ of cessation of exercise (see Fig 5A). Importantly, this effect was evident in both Group A (pre: $65.0 \pm 12.0 \mu \mathrm{M}$; 3h: $122.8 \pm 39.9 \mu \mathrm{M} ; \mathrm{P}<0.05$ [1-way ANOVA]), and Group B (pre: 46.9 $\pm 15.0 \mathrm{nM} ; 3 \mathrm{~h}$ : 113.7 $\pm 11.0 \mathrm{nM} ; \mathrm{P}<0.05$ [1-way ANOVA]), while direct comparison of the two groups showed no significant differences between their $[\mathrm{ROS}]_{\text {cyto }}$ responses before, during or after exercise $(\mathrm{P}>0.05$ [2-way ANOVA]). These values are in line with data obtained using a similar approach in isolated mouse muscle fibres, when baseline and postexercise intracellular ROS concentrations of $\sim 10-100 \mathrm{nM}$ and $100-200 \mathrm{nM}$, respectively, were obtained [6]. Similarly, as shown in Fig 5B, no differences in AMPK phosphorylation (measured pre- and $3 \mathrm{~h}$ post-exercise) were seen between Groups A and B ( $\mathrm{P}>0.05$ [2-sample t-test] in both cases).

Importantly, as shown in Fig 6, despite there being no inter-group differences with regard to $[\mathrm{ROS}]_{\mathrm{cyto}}$ or AMPK, significant (or borderline-significant) increases in expression of PPAR $\gamma /$ PGC-1 $\alpha$-regulated genes were observed in samples taken from Group A within $3 \mathrm{~h}$ of exercise (PPAR $\gamma$ and PGC-1 $\alpha(\mathrm{P}<0.05$ [1-way ANOVA]); LXR $\alpha$ and ABCA1 $(\mathrm{P}<0.10$ [1-way ANOVA])). Importantly, such increases were not

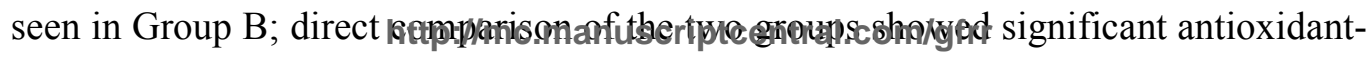


associated blunting of the response to exercise with regard to expression of PPAR $\gamma$ $(\mathrm{P}<0.01$ [2-way ANOVA]) and PGC-1 $\alpha(\mathrm{P}<0.05$ [2-way ANOVA]).

\section{Discussion.}

In the current study, we present data which support the view that exercise is an oxidative stressor (reviewed in [1,2,5]), and elucidate several downstream consequences of exercise-induced oxidative stress with regard to monocyte cell signalling.

As previously stated, there is a need to establish whether the exercise-associated cell signalling effects demonstrated in skeletal myocytes by Ristow et al [21] also occur in non-muscle cell types such as monocytes. ROS are able to act as autocrine factors that trigger cell signalling responses [2,7,46]; however, increased ROS generation by mitochondria during exercise is unlikely to be the case in monocytes, as vascular cells are dependent primarily on glycolysis for their energetic demands [37,47], and so monocytes would not be expected to generate large amounts of mitochondrial ROS. Moreover, we have previously shown that monocytic expression of the NADPH oxidase catalytic subunit NOX2 decreased after exercise [33], which indicates that NADPH-catalysed endogenous generation of ROS is unlikely to increase following exercise. Instead, paracrine/endocrine actions of skeletal muscle-derived ROS (ie. diffusion of ROS from contracting myocytes into the external milieu, and possibly into the circulation $[1,2]$ ) are likely to be responsible for exercise-triggered signalling responses within monocytes. This suggestion is supported by our previous observation that exercise is associated with decreased GSH in the serum $[33,34]$. Once in the circulation, muscle-derived ROS may either oxidise circulating macromolecules such as lipoprotein particles (as supported by our previous observation that exercise is associated with transient increases in serum oxLDL [32]), http://mc.manuscriptcentral.com/gfrr 
and/or may diffuse into circulating cells such as monocytes. The present study attempted to establish which of these two possibilities is the source of the exercisetriggered monocyte signalling responses seen previously [32-35].

As previous in-vitro studies have shown that exposure of cultured myotubes to prooxidants induces signalling responses involving upregulation of numerous genes, including PGC-1 $\alpha[7,40]$, we initially investigated the responses of cultured THP-1 monocytic cells to menadione (a cell-permeable $\mathrm{H}_{2} \mathrm{O}_{2}$ donor) or oxLDL (a bloodborne marker of oxidative stress). We found that responses were prevented (or at least significantly blunted) if menadione was co-administered alongside vitamin $\mathrm{C}$, or if cells were treated with non-oxidised LDL rather than oxLDL. Hence, in both cases, it seems plausible to conclude that oxidative stress is the 'trigger' for these responses, and therefore that these in-vitro experiments are acceptable models for the exerciseassociated oxidative stress seen in-vivo. Figs 1-3 show that AMPK $\alpha 1$ was phosphorylated within $1 \mathrm{~h}$ of menadione-triggered increases in $[\mathrm{ROS}]_{\mathrm{cyto}}$, and that this appeared to be followed by phosphorylation of PGC-1 $\alpha$, and upregulation of several PPAR $\gamma /$ PGC- $1 \alpha$ target genes, with these effects being blunted by co-administration of vitamin $\mathrm{C}$ alongside menadione. Conversely, while Fig 4 shows that oxLDL - but not LDL - upregulates several PPAR $\gamma /$ PGC- $1 \alpha$ target genes, Figs 1 and 2 suggest that this effect occurred without phosphorylation of either AMPK $\alpha 1$ or PGC-1 $\alpha$. Given the data in Fig 4C, and the previous demonstrations by ourselves and others that the oxLDL component 13-HODE is a PPAR $\gamma$ ligand [34,36], it seems likely that liganddependent PPAR $\gamma$ activation is responsible for the upregulation of PPAR $\gamma / \mathrm{PGC}-1 \alpha$ target genes in these oxLDL experiments.

Thus, we concluded that both $[\mathrm{ROS}]_{\mathrm{cyto}}$-triggered upstream kinase cascades and direct

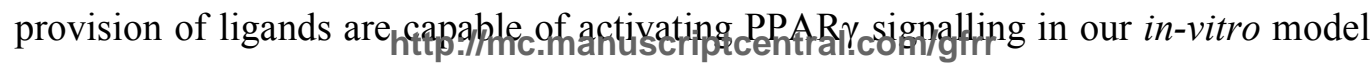


system. We next carried out an in-vivo series of experiments that aimed to elucidate which of these possibilities is responsible for the observed effect of exercise in activating PPAR $\gamma$ signalling within monocytes, and also whether dietary antioxidant supplementation could block these effects.

Although there was some variability within the dataset shown in Fig 6, PPAR $\gamma /$ PGC$1 \alpha$ target gene expression broadly increased following exercise, with these exerciseassociated gene expression effects being blunted by dietary antioxidant supplementation. However, while Fig $5 \mathrm{~A}$ showed that $[\mathrm{ROS}]_{\text {cyto }}$ increased postexercise, this effect occurred to similar extents in both the exercise-alone or exerciseplus-antioxidants groups, and furthermore no differences in AMPK $\alpha 1$ activation status could be detected between the two groups (see Fig 5B). Therefore, it is unlikely that $[\mathrm{ROS}]_{\text {cyto-mediated }}$ AMPK phosphorylation could be responsible for the exercise-associated activation of PPAR $\gamma$ signalling observed in the RT-PCR data obtained from the exercise-alone group, or that an effect of antioxidants on $[\mathrm{ROS}]_{\mathrm{cyto}}-$ mediated AMPK activation could be responsible for the 'blunting' effects seen in the comparable data from the exercise-plus-antioxidants group. Rather, it seems that, although exercise-associated increases in $[\mathrm{ROS}]_{\mathrm{cyto}}$ do occur, unlike menadioneinduced in-vitro oxidative stress (whose impact involved larger increases in $[\mathrm{ROS}]_{\text {cyto}}$ ), these increases apparently do not couple with downstream PPAR $\gamma$ signalling effects in-vivo.

Conversely, antioxidant supplementation is known to prevent increases in oxidation of extracellular [ie. serum/plasma] lipids/lipoproteins, in the contexts of both pharmacologically-induced oxidative stress [48] and exercise [21,49] (as measured by GC-MS and TBARS assays, respectively). Therefore, given the differential effects seen for oxLDL versus non-oxidised LDL treatments in Fig 4, the 'blunting' effects http://mc.manuscriptcentral.com/girr 
seen in Fig 6 suggest that antioxidant-preventable exercise-associated monocytic PPAR $\gamma$ signalling may be mediated by increased generation of blood-borne PPAR $\gamma$ ligands via oxidation of lipoproteins (following exercise-associated transient increases in oxidative stress), rather than via $[\mathrm{ROS}]_{\mathrm{cyto}}$-mediated AMPK activation.

Exercise-related signalling events in monocytes have not been as intensively studied as those in skeletal muscle, and to our knowledge this study is novel in that it provides evidence extending previous observations concerning the ability of antioxidants to block exercise-triggered skeletal myocyte signalling responses [21-26] to an additional cell type, namely the monocyte. In a broader sense, the findings of the present study support the view that exercise is a systemic phenomenon whose impact is not limited to skeletal muscle. It should be acknowledged that several differences exist between the respective exercise-triggered pathways in muscle and monocytes, most notably that PPAR $\gamma$ controls expression of different genes, and so exerts different effects, in monocytes and muscle [11,32]. Nevertheless, PPAR $\gamma$ signalling is involved in regulation and integration of inflammation and lipid metabolism throughout the whole body, with PPAR $\gamma$ carrying out distinct but complementary functions in diverse tissues [20]. For example, exercise-triggered PPAR $\gamma$ signalling is involved in both the regulation of adipocyte triglyceride hydrolysis/esterification processes so as to boost release of fatty acids into the bloodstream [50], and the increased expression of skeletal muscle genes linked to oxidative metabolism of fats [10]. Thus, although different genes are activated in different tissues, a complementary array of effects is induced, and the systemic impact is broadly beneficial in the context of T2D. Our study's identification of monocytes as an exercise-responsive cell-type, in which $\operatorname{PPAR} \gamma$ can be activated to upregulate beneficial anti-oxidant/anti-inflammatory/lipid-handling genes $[30,32-36,44]$, is in line with this concept. http://mc.manuscriptcentral.com/gfrr 
The current study has several limitations, including the small cohort size (with the accompanying variability in the data obtained), and the fact that participants were followed up for only $24 \mathrm{~h}$ after a single bout of exercise (rather than more prolonged exercise programmes being investigated). With regard to follow-up, it should be noted that targets of PPAR $\gamma / \mathrm{PGC}-1 \alpha$ have longer half-lives at the protein - and therefore the functional - level, than at the mRNA level. Thus, although mRNA expression had declined by $24 \mathrm{~h}$ after each exercise bout, effects on monocyte function are likely to persist for longer than $24 \mathrm{~h}$ after each exercise bout. Importantly, the PPAR $\gamma / \mathrm{PGC}-1 \alpha$ signalling effects seen here were similar - but less pronounced - to those seen previously in 8-week exercise programmes ( $\geq 3$-fold increases [32-35]); thus, it is possible that the effects of each individual exercise bout may accumulate, so that after an extended programme of regular exercise larger, sustained effects are evident. Another limitation is the lack of direct measurement of the impact of antioxidant supplementation on blood-borne oxLDL levels; however, it should be noted that several previous studies have shown that antioxidant supplementation prevents exercise-induced increases in oxidised lipids/lipoproteins [21,49], and so we feel justified in tentatively linking the observed blunting of exercise-induced upregulation of the above PPAR $\gamma /$ PGC- $1 \alpha$ target genes to prevention of oxLDL generation in our exercise-plus-antioxidant cohort.

In conclusion, exercise-associated activation of monocytic PPAR $\gamma$ signalling, and blunting of this response in participants undertaking dietary antioxidant signalling alongside exercise, were seen in the current study. It should be noted that, while parameters relevant to cardiovascular risk such as blood lipids and insulin sensitivity were not directly measured in this study (which was designed to be primarily mechanistic in nature), our previous exercise studies have demonstrated that enhanced http://mc.manuscriptcentral.com/gfrr 
monocytic PPAR $\gamma / \mathrm{PGC}-1 \alpha$ target gene expression positively correlates with increased HDL-C [32], and also with improved insulin sensitivity [Ruffino, personal communication]. Also, although the current study involved healthy participants, it should be noted that individuals with T2D exhibit decreased PGC-1 $\alpha$ [51] and PPAR $\gamma$ [52]. Therefore, if individuals with T2D were to respond in a similar manner to the participants in the current study - and T2D and non-T2D cohorts have been shown to respond in a similar manner to exercise $[3,53]$ - it is possible that the exerciseassociated effects seen here could help normalise PGC-1 $\alpha / \mathrm{PPAR} \gamma$ signalling in T2D. Thus, novel signalling effects that are linked to exercise-associated transient increases in oxidative stress have been reported in the current study, and these may be associated with cardiovascular risk-lowering effects associated with upregulation of insulin-sensitising and/or lipid-handling genes within monocyte/macrophages, and so could potentially contribute to both the prevention of development of T2D in healthy or pre-diabetic individuals, and the normalisation of aberrant metabolic function in individuals with T2D. 
Acknowledgements. The excellent technical support of Gareth Walters, Luke Rofe, Hannah Newport, Paul Jones and Sean Duggan is gratefully acknowledged. NAD was the recipient of a NISCHR Welsh Office Research and Development PhD studentship (2009-2013). 


\section{Reference List.}

1. Jackson MJ. Control of reactive oxygen species production in contracting skeletal muscle. Antioxid Redox Signal. 15(9):2477-86, 2011.

2. Powers SK, Jackson MJ. Exercise-induced oxidative stress: cellular mechanisms and impact on muscle force production. Physiol Rev. 88(4):124376, 2008.

3. Hey-Mogensen M, Højlund K, Vind BF, Wang L, Dela F, Beck-Nielsen H, Fernström M, Sahlin K. Effect of physical training on mitochondrial respiration and reactive oxygen species release in skeletal muscle in patients with obesity and type 2 diabetes. Diabetologia. 53(9):1976-85, 2010.

4. Radak Z, Chung HY, Koltai E, Taylor AW, Goto S. Exercise, oxidative stress and hormesis. Ageing Res Rev. 7(1):34-42, 2007.

5. Vasilaki A, Mansouri A, Van Remmen H, van der Meulen JH, Larkin L, Richardson AG, McArdle A, Faulkner JA, Jackson MJ. Free radical generation by skeletal muscle of adult and old mice: effect of contractile activity. Aging Cell. 5(2):109-17, 2006.

6. Palomero J, Pye D, Kabayo T, Spiller DG, Jackson MJ. In situ detection and measurement of intracellular reactive oxygen species in single isolated mature skeletal muscle fibers by real time fluorescence microscopy. Antioxid Redox Signal. 10(8):1463-74, 2008.

7. McArdle F, Spiers S, Aldemir H, Vasilaki A, Beaver A, Iwanejko L, McArdle A, Jackson MJ. Preconditioning of skeletal muscle against contraction-induced damage: the role of adaptations to oxidants in mice. $J$ Physiol.561(Pt 1):233-44, 2004.

\section{Petridou A, Tsalouhidou S, Tsalis G, Schulz T, Michna H, Mougios V.} Long-term exercise increases the DNA binding activity of peroxisome 
proliferator-activated receptor gamma in rat adipose tissue. Metabolism. 56(8):1029-36, 2007.

9. Gibala MJ, McGee SL, Garnham AP, Howlett KF, Snow RJ, Hargreaves M. Brief intense interval exercise activates AMPK and p38 MAPK signaling and increases the expression of PGC-1alpha in human skeletal muscle. $J$ Appl Physiol. 106(3):929-34, 2009.

10. Mahoney DJ, Parise G, Melov S, Safdar A, Tarnopolsky MA. Analysis of global mRNA expression in human skeletal muscle during recovery from endurance exercise. FASEB J. 19(11):1498-500, 2005.

11. Keller P, Vollaard NB, Gustafsson T, Gallagher IJ, Sundberg CJ, Rankinen T, Britton SL, Bouchard C, Koch LG, Timmons JA. A transcriptional map of the impact of endurance exercise training on skeletal muscle phenotype. J Appl Physiol. 110(1):46-59, 2011.

12. Plutzky J. The potential role of PPARs on inflammation in type 2 diabetes and atherosclerosis. Am J Cardiol 92:34-41, 2003.

13. Smith SA. Central role of the adipocyte in the insulin-sensitizing and cardiovascular risk modifying actions of the thiazolidinediones. Biochimie. 85: 1219-1230, 2003.

\section{Lehmann JM, Moore LB, Smith-Oliver TA, Wilkison WO, Willson TM,} Kliewer SA. An antidiabetic thiazolidinedione is a high affinity ligand for peroxisome proliferator-activated receptor gamma (PPAR gamma). J Biol Chem. 270(22):12953-6, 1995.

15. DREAM (Diabetes REduction Assessment with ramipril and rosiglitazone Medication) Trial Investigators, Gerstein HC, Yusuf S, Bosch J, et al. Effect of rosiglitazone on the frequency of diabetes in patients with impaired glucose tolerance or impaired fasting glucose: a randomised controlled trial. 
16. Nissen SE, Wolski K. Effect of rosiglitazone on the risk of myocardial infarction and death from cardiovascular causes, N. Eng. J. Med. 356: 24572471, 2007.

17. Singh S, Loke YK, Furberg CD. Thiazolidinediones and Heart Failure: A Teleo-Analysis. Diabetes Care 30(8):2148-53, 2007.

18. Rosen CJ. Revisiting the Rosiglitazone story - lessons learned. New England Journal of Medicine. 363(9):803-6, 2010.

\section{Leal I, Romio SA, Schuemie M, Oteri A, Sturkenboom M, Trifirò G.} Prescribing pattern of glucose lowering drugs in the United Kingdom in the last decade: a focus on the effects of safety warnings about rosiglitazone. $\mathrm{Br} J$ Clin Pharmacol. 75(3):861-8, 2013.

20. Nunn AV, Bell J, Barter P. The integration of lipid-sensing and antiinflammatory effects: how the PPARs play a role in metabolic balance.Nucl Recept. 5(1):1-13, 2007.

21. Ristow M, Zarse K, Oberbach A, Klöting N, Birringer M, Kiehntopf M, Stumvoll M, Kahn CR, Blüher M. Antioxidants prevent health-promoting effects of physical exercise in humans. Proc Natl Acad Sci $U$ S A. 106(21):8665-70, 2009.

\section{Gomez-Cabrera MC, Domenech E, Romagnoli M, Arduini A, Borras C,} Pallardo FV, Sastre J, Viña J. Oral administration of vitamin C decreases muscle mitochondrial biogenesis and hampers training-induced adaptations in endurance performance. Am J Clin Nutr. 87(1):142-9, 2008.

23. Kang C, O'Moore KM, Dickman JR, Ji LL. Exercise activation of muscle peroxisome proliferator-activated receptor-gamma coactivator-1alpha signaling is redox sensitive. Free Radic Biol Med. 47(10):1394-400, 2009.

\section{Khassaf M, McArdle A, Esanu C, Vasilaki A, McArdle F, Griffiths RD,} Brodie DA, Jackson MJ. Effect of vitamin $C$ supplements on antioxidant http://mc.manuscriptcentral.com/gfrr 
defence and stress proteins in human lymphocytes and skeletal muscle. $J$ Physiol. 549(Pt 2):645-52, 2003.

\title{
25. Petersen AC, McKenna MJ, Medved I, Murphy KT, Brown MJ, Della Gatta P, Cameron-Smith D. Infusion with the antioxidant N-acetylcysteine attenuates early adaptive responses to exercise in human skeletal muscle. Acta Physiol (Oxf). 204(3):382-92, 2012.
}

\author{
26. Strobel NA, Peake JM, Matsumoto A, Marsh SA, Coombes JS, Wadley \\ GD. Antioxidant supplementation reduces skeletal muscle mitochondrial \\ biogenesis. Med Sci Sports Exerc. 43(6):1017-24, 2011.
}

27. Calabrese EJ, Baldwin LA. Defining hormesis. Hum Exp Toxicol. 21(2):917, 2002.

28. Lowe DA, Warren GL, Ingalls CP, Boorstein DB, Armstrong RB. Muscle function and protein metabolism after initiation of eccentric contractioninduced injury. J Appl Physiol. 1995 Oct;79(4):1260-70.

29. Ricote M, Huang JT, Welch JS, Glass CK.The peroxisome proliferatoractivated receptor(PPARgamma) as a regulator of monocyte/macrophage function. J Leukoc Biol. 66(5):733-9, 1999.

30. Hevener AL, Olefsky JM, Reichart D, Nguyen MT, Bandyopadyhay G, Leung HY, Watt MJ, Benner C, Febbraio MA, Nguyen AK, Folian B, Subramaniam S, Gonzalez FJ, Glass CK, Ricote M. Macrophage PPAR $\gamma$ is required for normal skeletal muscle and hepatic insulin sensitivity and full antidiabetic effects of thiazolidinediones J. Clin. Invest. 117:1658-1669, 2007.

31. Gratchev A, Sobenin I, Orekhov A, Kzhyshkowska J. Monocytes as a diagnostic marker of cardiovascular diseases. Immunobiology. 217(5):476-82, 2012. 
32. Butcher, L., Backx, K., Roberts, A., Thomas, A., Webb, R., and Morris, K. Low-intensity exercise exerts beneficial effects on plasma lipids via PPAR $\gamma$. Medicine \& Science in Sports \& Exercise. 40 (7): 1-7, 2008.

33. Moir, H., Hughes, M.G., Potter, S., Sims, C., Butcher, L.R., Davies, N.A.,Verheggen, K, Jones, K.P., Thomas, A.W., and Webb, R. Exerciseinduced Immuno-suppression: The Roles of Reactive Oxygen Species and AMPK Dephosphorylation within Immune Cells. J Applied Physiol 108 (5):1284-92, 2010.

34. Thomas AW, Davies NA, Moir H, Watkeys L, Ruffino JS, Isa SA, et al. Exercise-associated generation of PPAR $\gamma$ ligands activates PPAR $\gamma$ signalling events and upregulates genes related to lipid metabolism. J Appl Physiol. 112(5):806-15, 2012.

35. Yakeu, G. Butcher, L. Isa, S. Webb, R. Roberts, A. Thomas, et al.. Lowintensity exercise triggers monocyte polarisation into the M2 antiinflammatory phenotype. Atherosclerosis 212: 668-673, 2010.

36. Nagy L, Tontonoz P, Alvarez JGA, Chen H, and Evans RM. Oxidized LDL regulates macrophage gene expression through ligand activation of PPAR $\gamma$. Cell. 93: 229-240, 1998.

37. Marsin AS, Bouzin C, Bertrand L, Hue L. The stimulation of glycolysis by hypoxia in activated monocytes is mediated by AMP-activated protein kinase and inducible 6-phosphofructo-2-kinase. J Biol Chem. 277:30778-83, 2002.

38. Toyoda T, Hayashi T, Miyamoto L, Yonemitsu S, Nakano M, Tanaka S. Possible involvement of AMPK $\alpha 1$ in oxidative stress-stimulated glucose transport in skeletal muscle. Am. J. Physiol. 287: E166-E173, 2004.

39. Jäger S, Handschin C, St-Pierre J, Spiegelman BM. AMP-activated protein kinase (AMPK) action in skeletal muscle via direct phosphorylation of PGC-

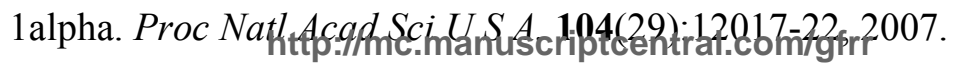


40. Irrcher I, Ljubicic V, Hood DA. Interactions between ROS and AMPK activity in the regulation of PGC-1alpha transcription in skeletal muscle cells Am J Physiol Cell Physiol. 296(1):C116-23, 2009.

41. Tsuchiya, S., Yamabe, M., Yamaguchi, Y., Kobayashi, Y., Konno, T., K. Tada. Establishment and Characterization of a Human Acute Monocytic Leukemia Cell line (THP-1 cells). Int J Cancer. 26(2):171-176, 1980.

42. Hirpara JL, Clément MV, Pervaiz S. Intracellular acidification triggered by mitochondrial-derived hydrogen peroxide is an effector mechanism for druginduced apoptosis in tumor cells. J Biol Chem. 276(1):514-21,2001.

43. Hardie DG, Hawley SA, and Scott JW. AMP-activated protein kinase development of the energy sensor concept. J. Physiol. 574: 7-15, 2006.

44. Hodgkinson CP, Ye S. Microarray analysis of peroxisome proliferatoractivated receptor-gamma induced changes in gene expression in macrophages. Biochem Biophys Res Commun. 308(3):505-10, 2003.

45. Hondares E, Mora O, Yubero P, Rodriguez de la Concepción M, Iglesias R, Giralt M, Villarroya F. Thiazolidinediones and rexinoids induce peroxisome proliferator-activated receptor-coactivator (PGC)-1alpha gene transcription: an autoregulatory loop controls PGC-1alpha expression in adipocytes via peroxisome proliferator-activated receptor-gamma coactivation. Endocrinology. 147(6):2829-38, 2006.

46. Erusalimsky JD and Moncada S. Nitric oxide and mitochondrial signaling: from physiology to pathophysiology. Arterioscler Thromb Vasc Biol. 27(12): 2524-31, 2007.

47. Quintero M, Colombo SL, Godfrey A Moncada S. Mitochondria as signalling organelles in the vascular endothelium. Proc. Nat. Acad. Sci. 103: 5379-5384, 2006. 
48. Chen K, Suh J, Carr AC, Morrow JD, Zeind J, Frei B. Vitamin C suppresses oxidative lipid damage in vivo, even in the presence of iron overload. Am J Physiol Endocrinol Metab. 279(6):E1406-12, 2000.

49. Higashida K, Kim SH, Higuchi M, Holloszy JO, Han DH. Normal adaptations to exercise despite protection against oxidative stress. Am J Physiol Endocrinol Metab. 301(5):E779-84, 2011.

50. Steinberg GR. Role of AMPK in regulating fatty acid metabolism during exercise. Appl Physiol Nutr Metab. 34(3):315-22, 2009.

51. Patti ME, Butte AJ, Crunkhorn S, Cusi K, Berria R, Kashyap S, Miyazaki Y, Kohane I, Costello M, Saccone R, Landaker EJ, Goldfine AB, Mun E, DeFronzo R, Finlayson J, Kahn CR, Mandarino LJ. Coordinated reduction of genes of oxidative metabolism in humans with insulin resistance and diabetes: Potential role of PGC1 and NRF1. Proc Natl Acad Sci U S A. 100(14):8466-71, 2003.

52. Moller DE. Potential role of TNF-alpha in the pathogenesis of insulin resistance and type 2 diabetes. Trends Endocrinol Metab. 11(6):212-7, 2000.

\section{Phielix E, Meex R, Moonen-Kornips E, Hesselink MK, Schrauwen P.} Exercise training increases mitochondrial content and ex vivo mitochondrial function similarly in patients with type 2 diabetes and in control individuals. Diabetologia. 53(8):1714-21, 2010. 


\section{Figure Legends.}

Fig 1: The Effect of Oligomycin, Menadione \pm Vitamin $C$ or oxidised LDL on

THP-1 AMPKa1 phosphorylation. THP-1 cells were treated for $1 \mathrm{~h}$ with either oligomycin $(1 \mu \mathrm{M}$; black bar), menadione $(15 \mu \mathrm{M}$; dark grey bar), menadione plus vitamin $\mathrm{C}(15 \mu \mathrm{M}$ and $62.5 \mu \mathrm{M}$; medium grey bar), or oxidised LDL $(1 \mu \mathrm{g} / \mathrm{mL}$; light grey bar), before either being subjected to loading with the ROS-sensitive dye $\mathrm{H}_{2}$ DCFDA and determination of [ROS $]_{\text {cyto }}$ using flow cytometry (A), or harvesting of total protein extracts, and subjecting to Western Blotting using anti-AMPK $\alpha 1$ $(1: 1000)$ or anti-p-AMPK (1:500) $1^{\circ}$ antibodies ((B): Representative images; (C): densitometric data (ie. phosphorylated AMPK:total AMPK $\alpha 1$ ) summarised in graphical form $(\mathrm{n}>3 ; * P<0.05))$.

Fig 2: The Effect of Oligomycin or Menadione \pm Vitamin $C$ on THP-1 expression of different forms of PGC-1 $\alpha$. THP-1 cells were treated for $1 \mathrm{~h}$ with either oligomycin $(1 \mu \mathrm{M}$; black bars $)$, menadione $(15 \mu \mathrm{M}$; dark grey bar), menadione plus vitamin $\mathrm{C}(15 \mu \mathrm{M}$ and $62.5 \mu \mathrm{M}$; medium grey bar), oxidised LDL $(1 \mu \mathrm{g} / \mathrm{mL}$; light grey bar), or non-oxidised LDL $(1 \mu \mathrm{g} / \mathrm{mL}$; white bar) before harvesting of total protein extracts, and subjecting to Western Blotting using anti-PGC-1 $\alpha(1: 500) 1^{\circ}$ antibodies. (A): Representative images; (B): densitometric data (ie. 115KDa band:total PGC-1 $\alpha$ doublet) summarised in graphical form $(\mathrm{n}>3 ; * P<0.05)$.

Fig 3: The Effect of Oligomycin or Menadione \pm Vitamin C on PGC-1 $\alpha /$ PPAR Target Gene Expression. THP-1 cells were treated for up to $72 \mathrm{~h}$ with either oligomycin $(1 \mu \mathrm{M}$; dark grey bars), menadione $(15 \mu \mathrm{M}$; medium grey bars), or menadione plus vitamin $\mathrm{C}(15 \mu \mathrm{M}$ and $62.5 \mu \mathrm{M}$; white bars), before harvesting of total RNA samples and determination of mononuclear cell PGC-1 $\alpha$ (A), PPAR $\gamma(\mathbf{B})$, LXR $\alpha(\mathbf{C})$, and ABCA1 (D) mRNA levels, as carried out via SYBR Green RT-PCR $\left.\left(\mathrm{n}>3 ; * * P<0.01 ; * P<0.05 ;{ }^{*}\right) P<0.10\right)$. 
Fig 4: The Effect of oxidised LDL, non-oxidised LDL or 13-HODE on PGC-

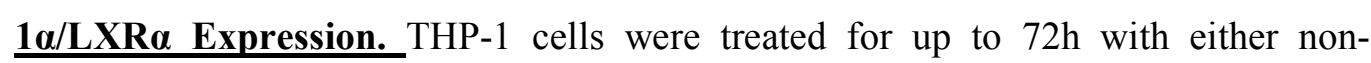
oxidised LDL $(1 \mu \mathrm{g} / \mathrm{mL}$; white bars in $(\mathbf{A}) /(\mathbf{B}))$, oxidised LDL $(1 \mu \mathrm{g} / \mathrm{mL}$; grey bars in (A) $/(\mathbf{B}))$, or 13-HODE $(5 \mu \mathrm{M}$; all bars in $(\mathbf{C}))$, before harvesting of total RNA samples and semi-quantitative determination of mononuclear cell PGC-1 $\alpha(\mathbf{A}, \mathbf{C})$ and LXR $\alpha$ (B, C) mRNA levels, as carried out via SYBR Green. Also, THP-1 cells were treated for $48 \mathrm{~h}$ with either menadione $(15 \mu \mathrm{M}$; dark grey bars), menadione plus vitamin $\mathrm{C}$ $(15 \mu \mathrm{M}$ and $62.5 \mu \mathrm{M}$; medium grey bars), oxidised LDL $(1 \mu \mathrm{g} / \mathrm{mL}$; light grey bars), or non-oxidised LDL $(1 \mu \mathrm{g} / \mathrm{mL}$; white bars) before harvesting of total protein extracts, and subjecting to Western Blotting using anti-PGC-1 $\alpha$ (1:500) or anti- $\beta$-actin (1:2000) $1^{\circ}$ antibodies. (D): Representative images; (E): densitometric data (ie. $115 \mathrm{KDa}$ band:total doublet, normalised to $\beta$-actin in each case) summarised in graphical form ( $\mathrm{n}>3$ in all cases; $* * P<0.01 ; * P<0.05)$.

Fig 5: The Effect of Exercise on Intracellular ROS Levels, and on AMPK activation in Peripheral Mononuclear Cells. Samples were obtained from 2 cohorts of exercising participants (exercise alone (white bars); exercise plus antioxidants (vitamins C (1000mg/day) and E (400IU/day) for four weeks prior to exercise; grey bars); $45 \mathrm{~min}$ of cycling at $70 \%$ max in both cases). (A): Mononuclear cells were loaded with the ROS-sensitive dye $\mathrm{H}_{2}$ DCFDA and monocyte $[\mathrm{ROS}]_{\text {cyto }}$ determined using flow cytometry for samples taken pre, post, $1.5 \mathrm{~h}, 3 \mathrm{~h}$ and $24 \mathrm{~h}$ following exercise. (B): Total protein extracts were harvested and subjected to Western Blotting using antiAMPK $\alpha 1$ (1:1000) or anti-p-AMPK (1:500) $1^{\circ}$ antibodies. Representative images of phosphorylated AMPK:total AMPK $\alpha 1$ are shown for samples taken pre and 3h-post exercise $(\mathrm{n}=5$ in each case; $* P<0.05)$.

Fig. 6: The Effect of Exercise on PGC-1 $\alpha / P P A R \gamma$ Target Gene expression in Peripheral Mononuclear Cells. Peripheral mononuclear cell samples were obtained

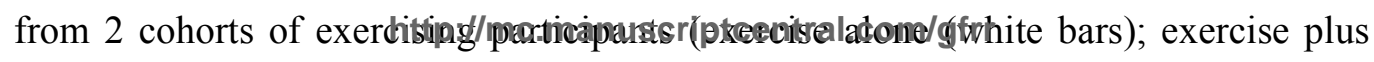


antioxidants (vitamins C (1000mg/day) and E (400IU/day) for four weeks prior to exercise; grey bars); $45 \mathrm{~min}$ of cycling at $70 \%$ max in both cases). Total RNA samples were harvested, and semi-quantitative determination of mononuclear cell PGC-1 $\alpha$ (A), PPAR $\gamma(\mathbf{B})$, LXR $\alpha(\mathbf{C})$ and ABCA1 (D) mRNA levels was carried out using RTPCR for samples taken pre-exercise, and $3 \mathrm{~h}$ and $24 \mathrm{~h}$ following exercise $(\mathrm{n}=5$ in each case; ** $P<0.01$; $P<0.05$; $\left.\left.{ }^{*}\right) P<0.10\right)$. 


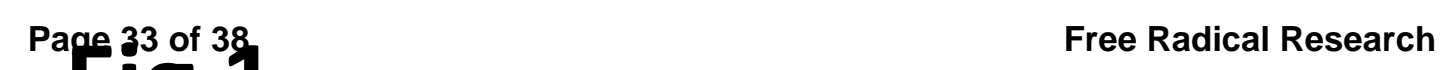

Fig 1

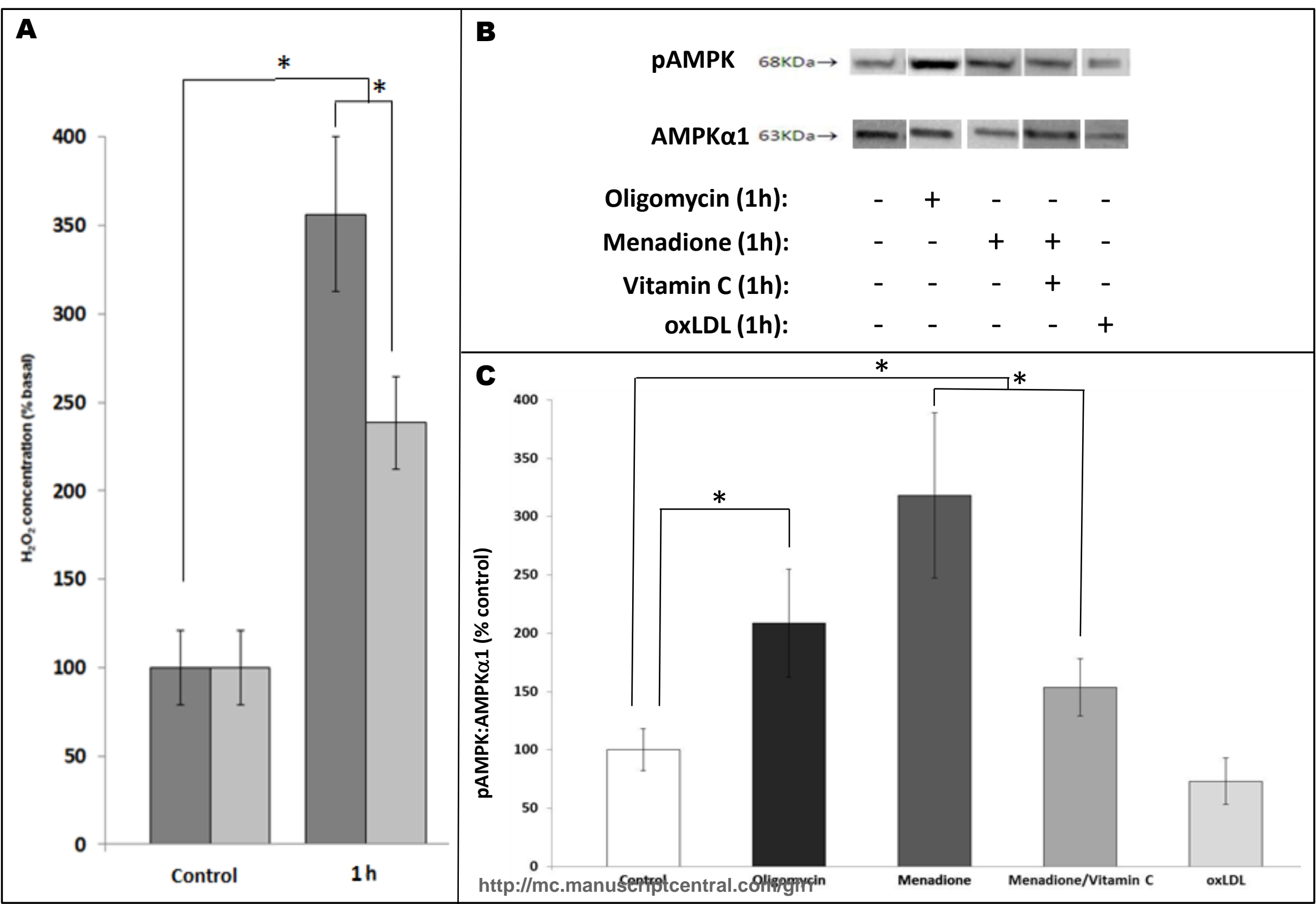


Free Radicat Research

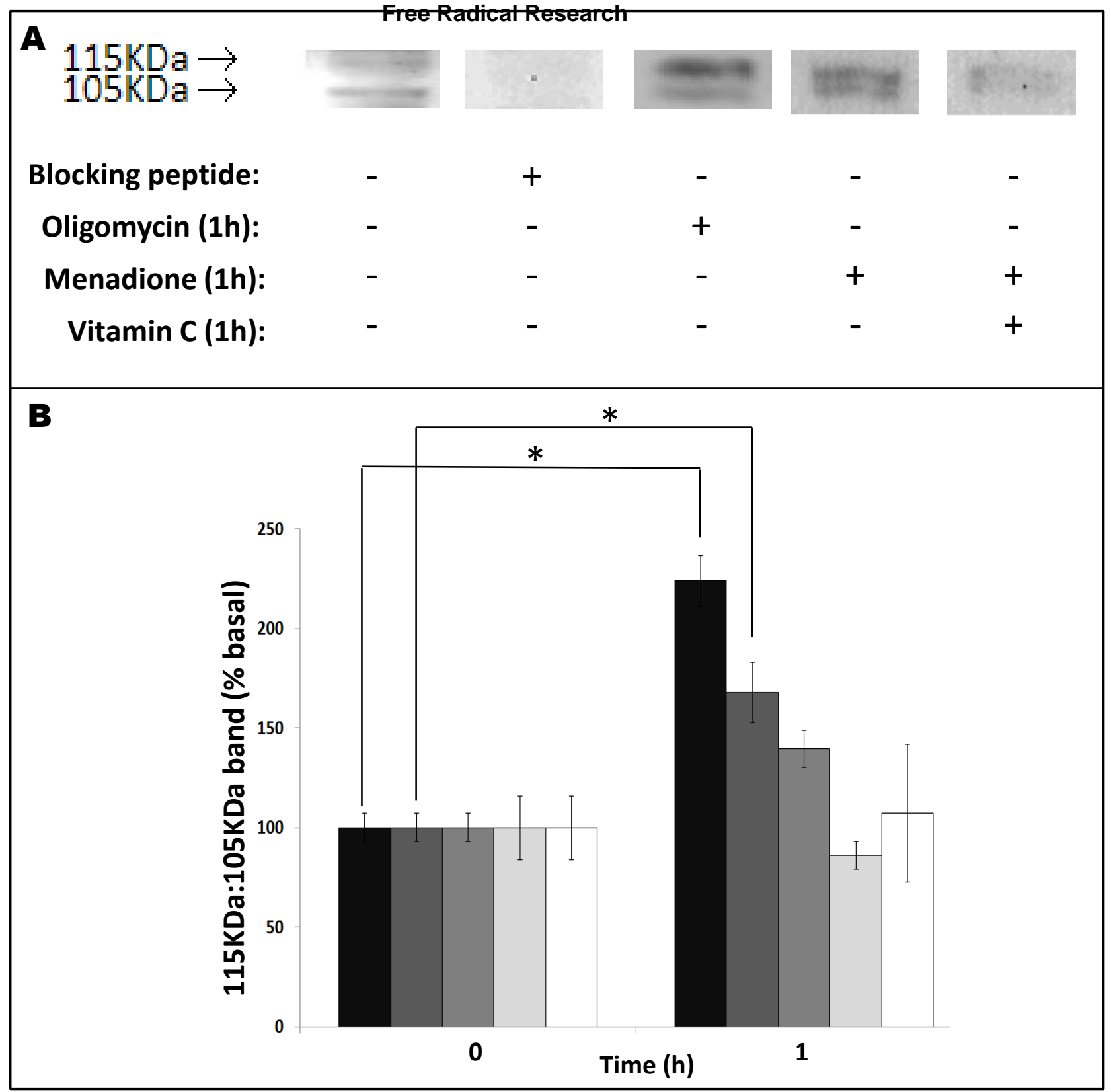

http://mc.manuscriptcentral.com/gfrr 


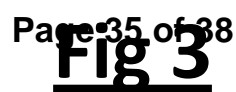

Free Radical Research

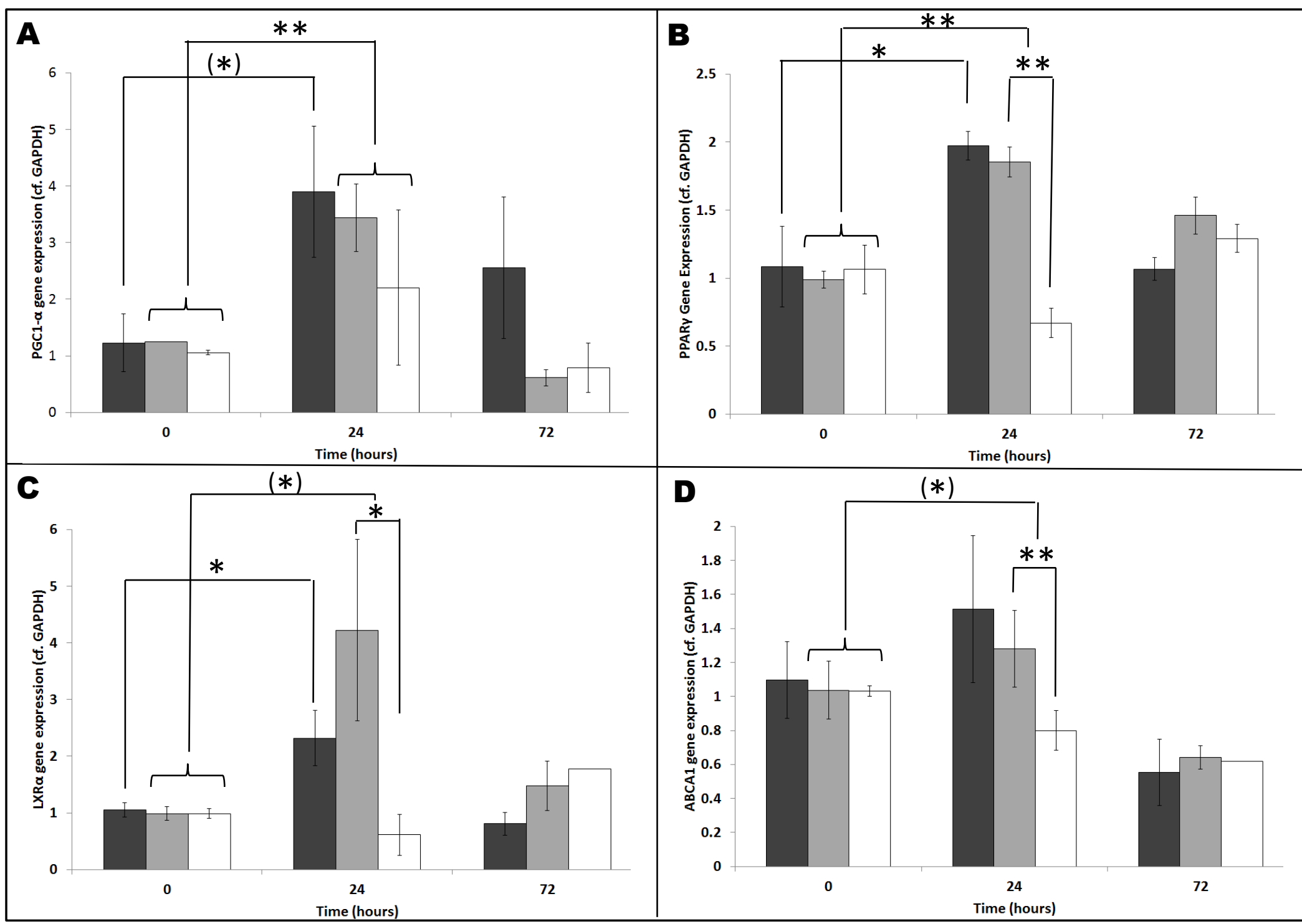

http://mc.manuscriptcentral.com/gfrr 
Fig 4

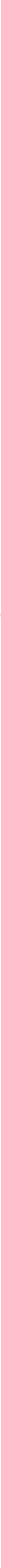

Free Radical Research

Page 36 of 38 


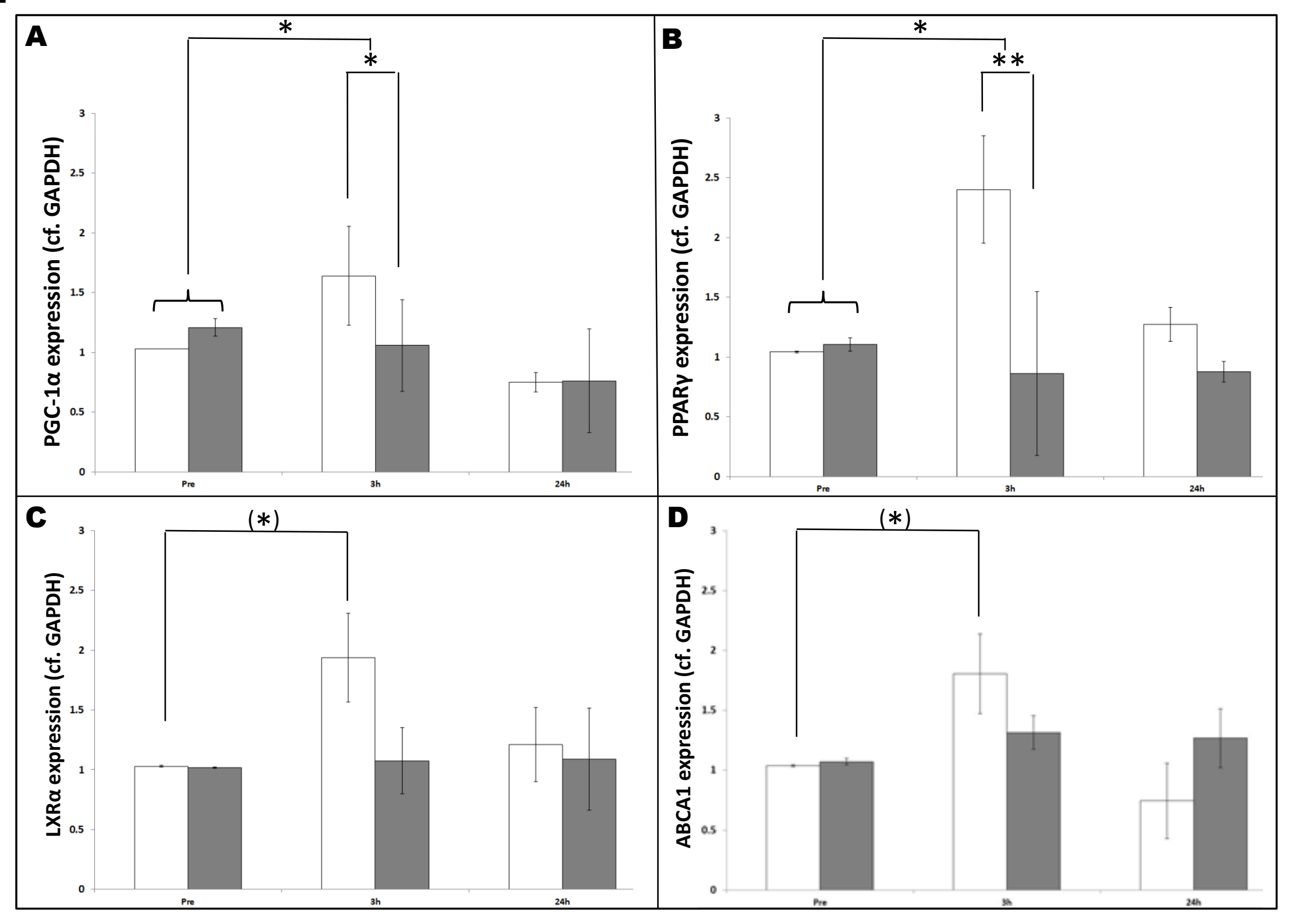

http://mc.manuscriptcentral.com/gfrr 